\title{
Evaluation of Cartilage Repair by Mesenchymal Stem Cells Seeded on a PEOT/PBT Scaffold in an Osteochondral Defect
}

Citation for published version (APA):

Barron, V., Merghani, K., Shaw, G., Coleman, C. M., Hayes, J. S., Ansboro, S., Manian, A., O’Malley, G., Connolly, E., Nandakumar, A., van Blitterswijk, C. A., Habibovic, P., Moroni, L., Shannon, F., Murphy, J. M., \& Barry, F. (2015). Evaluation of Cartilage Repair by Mesenchymal Stem Cells Seeded on a PEOT/PBT Scaffold in an Osteochondral Defect. Annals of Biomedical Engineering, 43, 2069-2082. https://doi.org/10.1007/s10439-015-1246-2

Document status and date:

Published: 29/09/2015

DOI:

10.1007/s10439-015-1246-2

Document Version:

Publisher's PDF, also known as Version of record

Document license:

Taverne

Please check the document version of this publication:

- A submitted manuscript is the version of the article upon submission and before peer-review. There can be important differences between the submitted version and the official published version of record.

People interested in the research are advised to contact the author for the final version of the publication, or visit the DOI to the publisher's website.

- The final author version and the galley proof are versions of the publication after peer review.

- The final published version features the final layout of the paper including the volume, issue and page numbers.

Link to publication

\footnotetext{
General rights rights.

- You may freely distribute the URL identifying the publication in the public portal. please follow below link for the End User Agreement:

www.umlib.nl/taverne-license

Take down policy

If you believe that this document breaches copyright please contact us at:

repository@maastrichtuniversity.nl

providing details and we will investigate your claim.
}

Copyright and moral rights for the publications made accessible in the public portal are retained by the authors and/or other copyright owners and it is a condition of accessing publications that users recognise and abide by the legal requirements associated with these

- Users may download and print one copy of any publication from the public portal for the purpose of private study or research.

- You may not further distribute the material or use it for any profit-making activity or commercial gain

If the publication is distributed under the terms of Article $25 \mathrm{fa}$ of the Dutch Copyright Act, indicated by the "Taverne" license above, 


\title{
Evaluation of Cartilage Repair by Mesenchymal Stem Cells Seeded on a PEOT/PBT Scaffold in an Osteochondral Defect
}

\author{
V. Barron, ${ }^{1,4}$ K. Merghani, ${ }^{1}$ G. Shaw,${ }^{1}$ C. M. Coleman, ${ }^{1}$ J. S. Hayes, ${ }^{1}$ S. Ansboro, ${ }^{1}$ A. Manian, ${ }^{1}$ \\ G. O’Malley, ${ }^{1}$ E. Connolly, ${ }^{1}$ A. Nandakumar,${ }^{3}$ C. A. van Blitterswijk, ${ }^{3}$ P. Habibovic, ${ }^{3}$ L. Moroni, ${ }^{3}$ \\ F. Shannon, ${ }^{2}$ J. M. Murphy, ${ }^{1}$ and F. Barry ${ }^{1}$

\begin{abstract}
${ }^{1}$ Regenerative Medicine Institute, National University of Ireland Galway, Galway, Ireland; ${ }^{2}$ Discipline of Surgery, Clinical Regeneration, Institute for Biomedical Technology and Technical Medicine (MIRA), University of Twente, Enschede, The Netherlands; and ${ }^{4}$ Materials Research Institute, Athlone Institute of Technology, Co, Westmeath, Ireland
\end{abstract} \\ Science Institute, Galway University Hospital, National University of Ireland Galway, Galway, Ireland; ${ }^{3}$ Department of Tissue
}

(Received 2 October 2014; accepted 7 January 2015; published online 15 January 2015)

Associate Editor Kent Leach oversaw the review of this article.

\begin{abstract}
The main objective of this study was to evaluate the effectiveness of a mesenchymal stem cell (MSC)-seeded polyethylene-oxide-terephthalate/polybutylene-terephthalate (PEOT/PBT) scaffold for cartilage tissue repair in an osteochondral defect using a rabbit model. Material characterisation using scanning electron microscopy indicated that the scaffold had a 3D architecture characteristic of the additive manufacturing fabrication method, with a strut diameter of $296 \pm 52 \mu \mathrm{m}$ and a pore size of $512 \pm 22 \mu \mathrm{m} \times 476 \pm 25 \mu \mathrm{m} \times 180 \pm 30 \mu \mathrm{m}$. In vitro optimisation revealed that the scaffold did not generate an adverse cell response, optimal cell loading conditions were achieved using $50 \mu \mathrm{g} / \mathrm{ml}$ fibronectin and a cell seeding density of $25 \times 10^{6}$ cells $/ \mathrm{ml}$ and glycosaminoglycan (GAG) accumulation after 28 days culture in the presence of TGF $\beta 3$ indicated positive chondrogenesis. Cell-seeded scaffolds were implanted in osteochondral defects for 12 weeks, with cellfree scaffolds and empty defects employed as controls. On examination of toluidine blue staining for chondrogenesis and GAG accumulation, both the empty defect and the cellseeded scaffold appeared to promote repair. However, the empty defect and the cell-free scaffold stained positive for collagen type I or fibrocartilage, while the cell-seeded scaffold stained positive for collagen type II indicative of hyaline cartilage and was statistically better than the cell-free scaffold in the blinded histological evaluation. In summary, MSCs in combination with a 3D PEOT/PBT scaffold created a reparative environment for cartilage repair.
\end{abstract}

Keywords-Additive manufacturing, 3D scaffold, PEOT/ PBT, Mesenchymal stem cells, Cartilage repair.

Address correspondence to J. M. Murphy, Regenerative Medicine Institute, National University of Ireland Galway, Galway, Ireland. Electronic mail: mary.murphy@nuigalway.ie

\section{INTRODUCTION}

Articular cartilage has a limited capacity for selfrepair and tissue damage as a result of osteoarthritis or trauma generally results in the lack of hyaline cartilage regeneration. Current surgical treatments for degenerative wear in the knee joint include microfracture, mosaicplasty, autologous chondrocyte implantation (ACI) or, more recently, matrix induced autologous chondrocyte implantation (MACI). ${ }^{2}$ Although in the shorter term these techniques improve mobility and alleviate pain, in many cases the repair tissue is fibrocartilaginous and lacks optimal biological and mechanical properties for long-term functional recovery. ${ }^{14}$ Over the last 20 years, cell therapies and tissue engineering strategies have been investigated and have shown potential for the repair/regeneration of hyaline cartilage. ${ }^{1}$ In particular, mesenchymal stem cells (MSCs) have shown promise as a suitable cell source as they can be harvested from bone marrow and other tissues, and expanded in culture to obtain large numbers of cells with chondrogenic potential. ${ }^{9}$

Current matrix- or scaffold-associated strategies for cartilage tissue engineering rely on both non-degradable and biodegradable materials with structures optimized for cell seeding. There is now recognition that the mechanical properties, chemical composition, porosity and pore architecture of the scaffold play a very important role in cartilage repair. Indeed recent studies have focused on creating bio-functional scaffolds with structures and properties similar to native cartilage. $^{23,24,31}$ Previously, the authors developed a $3 \mathrm{D}$, open pore polyethylene oxide terephthalate poly- 
butylene terephthalate (PEOT/PBT) scaffold with mechanical properties and a chemical structure tailored for cartilage repair. ${ }^{5,18,21,22}$ After 14 days of subcutaneous implantation, this construct did not provoke an inflammatory response and was shown to be capable of supporting cartilaginous matrix deposition. ${ }^{32}$ In an attempt to provide an integrated bioengineering solution to a current unmet biomedical problem, it was hypothesized that, in combination to the fine-tuned mechanical properties, the addition of cells would provide biological cues for better repair.

To this end, porous PEOT/PBT scaffolds were fabricated by 3D-fiber deposition and the architecture was visualized using scanning electron microscopy (SEM). Upon confirmation that the scaffolds did not evoke an adverse cell response when grown in the presence of rabbit MSCs, cell seeding was optimized using a fibronectin coating, while biological cues for chondrogeneis were evaluated in vitro using a glycosaminoglycan accumulation (GAG) assay. Thereafter, the cell-seeded scaffolds were implanted in an osteochondral defect in a rabbit model. After 12-weeks implantation, hyaline cartilage repair was evaluated by histological staining, while blinded histological scoring was used to examine the effect of providing biological cues from MSCs implanted on the PEOT/PBT scaffold.

\section{MATERIALS AND METHODS}

\section{Materials}

A $55 / 45-\mathrm{wt} \%$ PEOT/PBT scaffold, created by $3 \mathrm{D}$ fiber deposition was employed in this study. Using a $3 \mathrm{D}$ printer, the scaffolds were produced at a melting temperature of $190^{\circ} \mathrm{C}$, an extrusion pressure of 4 bars, and an extrusion nozzle with an internal diameter of $0.7 \mathrm{~mm}$. A $0-90^{\circ}$ angle deposition pattern was followed in a layer-by-layer manner. The 3D architecture of the scaffold was imaged using SEM (Hitachi, S4700, UK). In brief, samples were sputter-coated with gold and imaged using a $15 \mathrm{kV}$ accelerating voltage for analysis of strut diameter, pore width, height and depth.

\section{In Vitro Optimization of the Scaffold}

\section{Cell Viability in the Presence of the Scaffold}

As part of the in vitro optimisation prior to implantation, it was necessary to show that chondrogenesis could occur. As a prelude to the in vitro chondrogenesis study, cell viability in the presence of the PEOT/PBT scaffold was evaluated. Rabbit MSC phenotype was confirmed by tri-lineage differentiation and surface marker expression using flow cytometry. Cells were positive for the MSC markers PDGFR $\alpha$, CD90, and CD49a and negative for CD34, CD45 and the human leukocyte antigen HLA-DR (data not shown). Thereafter, MSCs were seeded at a density of 20,000 cells $/ \mathrm{cm}^{2}$ and maintained for $24 \mathrm{~h}$ at $37{ }^{\circ} \mathrm{C}$ in a humidified atmosphere of $5 \% \quad \mathrm{CO}_{2}$ in cell culture medium consisting of alpha-minimum essential medium $(\alpha$-MEM-Gibco), $10 \%$ fetal bovine serum (FBS) serum, $1 \%$ penicillin/streptomycin $(\mathrm{P} / \mathrm{S})$ and $2 \%$ rabbit serum (RS). Thereafter scaffolds with dimensions $1 / 10$ of the total area of the well were placed directly on the cells and incubated for an additional $24 \mathrm{~h}$. An AlamarBlue $^{\mathrm{TM}}$ (AB) assay (Molecular Probes) was then employed to examine the metabolic activity of the cells by measuring the fluorescence intensity $(530 \mathrm{~nm}$ excitation/590 nm emission) on a microplate fluorescence reader (FLX800, Biotek Instruments Inc.) as per the manufacturer's instruction. As a method of control, rabbit MSCs seeded on tissue culture plastic were also examined $(n=6)$.

\section{Optimisation of Cell Loading Conditions}

Previous studies have shown that a cell seeding density of $25 \times 10^{6} \mathrm{MSCs} / \mathrm{ml}$ was required to achieve chondrogenesis in a 3D structure. ${ }^{10}$ In addition, it has also been shown that pre-coating the scaffolds with fibronectin enhances cell attachment. ${ }^{15}$ As a consequence, four concentrations of fibronectin $0,25,50$, and $100 \mu \mathrm{g} / \mathrm{ml}$ in PBS were evaluated as scaffold coating materials. After $1 \mathrm{~h}$ immersion in the fibronectin solutions, the PEOT/PBT scaffolds $(3 \mathrm{~mm}$ in diameter and $3 \mathrm{~mm}$ in height) were placed in a $3 \mathrm{ml}$ EST Z sterile vacutainer (BD). Using a cell seeding density of $25 \times 10^{6}$ cells $/ \mathrm{ml}$, a suspension of $1.2 \times 10^{6}$ rabbit MSCs (passage 1) in $50 \mu \mathrm{l}$ of incomplete chondrogenic medium (ICM) consisting of HG-DMEM supplemented with $100 \mathrm{nM}$ dexamethasone, $50 \mu \mathrm{g} / \mathrm{ml}$ ascorbic acid, $40 \mu \mathrm{g} / \mathrm{ml}$ L-Proline, $6.25 \mu \mathrm{g} / \mathrm{ml}$ selenous acid, $5.33 \mu \mathrm{g} / \mathrm{ml}$ linoleic acid, $1.25 \mathrm{mg} / \mathrm{ml}$ bovine serum albumin, $0.11 \mathrm{mg} / \mathrm{ml}$ sodium pyruvate and $1 \% \mathrm{P} / \mathrm{S}$ was added to the vacutainer. Using an 18-gage needle and a $10 \mathrm{ml}$ syringe the air was aspirated from each tube by drawing a vacuum and releasing three times. The tubes containing the cell-seeded scaffolds were placed in an incubator at $37{ }^{\circ} \mathrm{C}$ with $5 \% \mathrm{CO}_{2}$ for $1 \mathrm{~h}$ to allow cell attachment and then immersed in $1 \mathrm{ml}$ ICM to remove any unattached cells. Cell attachment was subsequently assessed by measurement of the total dsDNA content using a PicoGreen assay (Invitrogen). Cell distribution through the center of the scaffold was assessed using SEM. Cell-seeded scaffolds were fixed in a $2.5 \%$ solution of electron microscopy grade gluter- 
aldehyde, dehydrated in a series of alcohols from 50 to $100 \%$ for $5 \mathrm{~min}$ each, dried by evaporation of hexamethyldisilazane, gold-coated and imaged using SEM (Hitachi, UK) with an accelerating voltage of $15 \mathrm{kV}$.

\section{In Vitro Chondrogenesis}

Previous studies have shown that MSC differentiation is enhanced in a hypoxic environment. ${ }^{20}$ The differentiation behavior of the rabbit MSC-seeded scaffold was evaluated by measuring GAG accumulation after 21 days culture in both hypoxic and normoxic environments with and without the presence of transforming growth factor (TGF) $\beta 3$. In brief, upon optimization of the fibronectin coating concentration and $24 \mathrm{~h}$ culture in ICM, the rabbit MSC-seeded scaffolds were cultured in complete chondrogenic medium (CCM) consisting of ICM supplemented with $10 \mathrm{ng} / \mathrm{ml}$ TGF $\beta 3$ with medium changed every 2 days and cultured in either a hypoxic environment with 5\% $\mathrm{O}_{2}$ at $37{ }^{\circ} \mathrm{C}$ and $100 \%$ humidity or a normoxic environment with $21 \% \mathrm{O}_{2}$ at $37{ }^{\circ} \mathrm{C}$ and $100 \%$ humidity. As a method of control cell-seeded scaffolds were cultured in the absence of TGF $\beta 3$ in both environments. Thereafter, GAG accumulation was determined using a dimethlymethylene (DMMB) assay on papaindigested scaffolds with chondroitin-sulfate- 6 as a standard, while DNA was measured using a PicoGreen assay.

\section{Surgical Procedure}

$24 \mathrm{~h}$ prior to surgery, the PEOT/PBT scaffolds were coated with $50 \mu \mathrm{g} / \mathrm{ml}$ of fibronectin, seeded with rabbit MSCs at a density of $25 \times 10^{6}$ cells $/ \mathrm{ml}$ and cultured in ICM, as described above. Nine skeletally mature male white New Zealand rabbits, weighing at least $3 \mathrm{~kg}$, were used in this study. Both knees in each rabbit underwent surgery under sterile conditions. All procedures were conducted in accordance with University guidelines, ethical approval from the Animal Care and Research Ethics Committee at the National University of Ireland Galway and a license from the Irish Department of Health. Six rabbits were randomly assigned to receive a cell-free scaffold in the right knee $(n=6)$ and a cell-seeded scaffold in the left knee $(n=6)$, while the remaining three rabbits received an empty defect in both knees $(n=6)$, as a fibrocartilage control. Rabbits were anesthetized using a weight-adjusted dose of ketamine $(35 \mathrm{mg} / \mathrm{kg})$ and xyalazine $(10 \mathrm{mg} / \mathrm{kg})$ and $3 \mathrm{~mm}$ defects were created in the center of the medial femoral condyle using a drill with a previously sterilized $2.8 \mathrm{~mm}$ drill bit covered with a sterile sheath. The walls of the defect were finished with a curette. Thereafter, the cell-free and cell-seeded
PEOT/PBT scaffolds were press-fit into place, while the empty defects were left unfilled.

\section{Histological Evaluation}

At 12 weeks, the rabbits were sacrificed and after examination of gross surface morphology, the femoral condyles were removed and fixed in 10\% neutral buffered formalin and decalcified in Surgipath II for $2-3$ weeks. Samples were serially sectioned at $5 \mu \mathrm{m}$ intervals and stained with toluidine blue. Tissue sections were graded by four blinded reviewers, $1.5 \mathrm{~mm}$ into the defect using a modified O'Driscoll scoring system based on previous proof of concept studies for cell-laden scaffolds. ${ }^{13,30}$ This included evaluation of percentage of the defect filled by hyaline cartilage, articular surface continuity, tidemark, thickness of repair tissue and integration with native tissue. With respect to degenerative changes, these were evaluated in the repair tissue and adjacent tissue in addition to chondrocyte clustering.

\section{Immunohistological Staining for Collagen}

Immunohistochemistry was performed for Collagen type I and Collagen type II as described previously. ${ }^{25}$ Sections were treated with $4 \mathrm{mg} / \mathrm{ml}$ (Dako Pepsin S3002) for $30 \mathrm{~min}$ at room temperature for antigen retrieval prior to sequential incubation with a goat anti-type I collagen antibody (1:100, S1310-01; SouthernBiotech) or a mouse anti-type II collagen antibody (1:50, AF5710; Acris) at $4{ }^{\circ} \mathrm{C}$ overnight followed by a biotinylated rabbit anti-goat secondary (1:1000, 305-065-003; Jackson ImmunoResearch Inc.) for collagen type I and a goat anti-mouse (1:1000; KPL 71-00-29) for collagen type II for $30 \mathrm{~min}$ at room temperature.

\section{Statistical Analysis}

Where appropriate, results were represented as mean \pm standard error of the mean (SEM). The optimal fibronectin coating was evaluated using a student's t test with $p \leq 0.05$ considered significant. The GAG/ DNA accumulation was analyzed using two-way ANOVA to examine the effect of both culture environment and the presence of TGF $\beta 3$. The histological scoring was also evaluated using two-way ANOVA to examine variations between the groups, with $p \geq 0.05$ considered not significant (ns), $(*), p \leq 0.01$ very significant $(* *)$, with $p \leq 0.001\left(^{* * *}\right)$, and $p \leq 0.00001$ $(* * * *)$ considered extremely significant. Confidence of intervals at $95 \%$ was used to examine variations within groups. All data was analyzed using GraphPad Prism version 6 . 
(a)
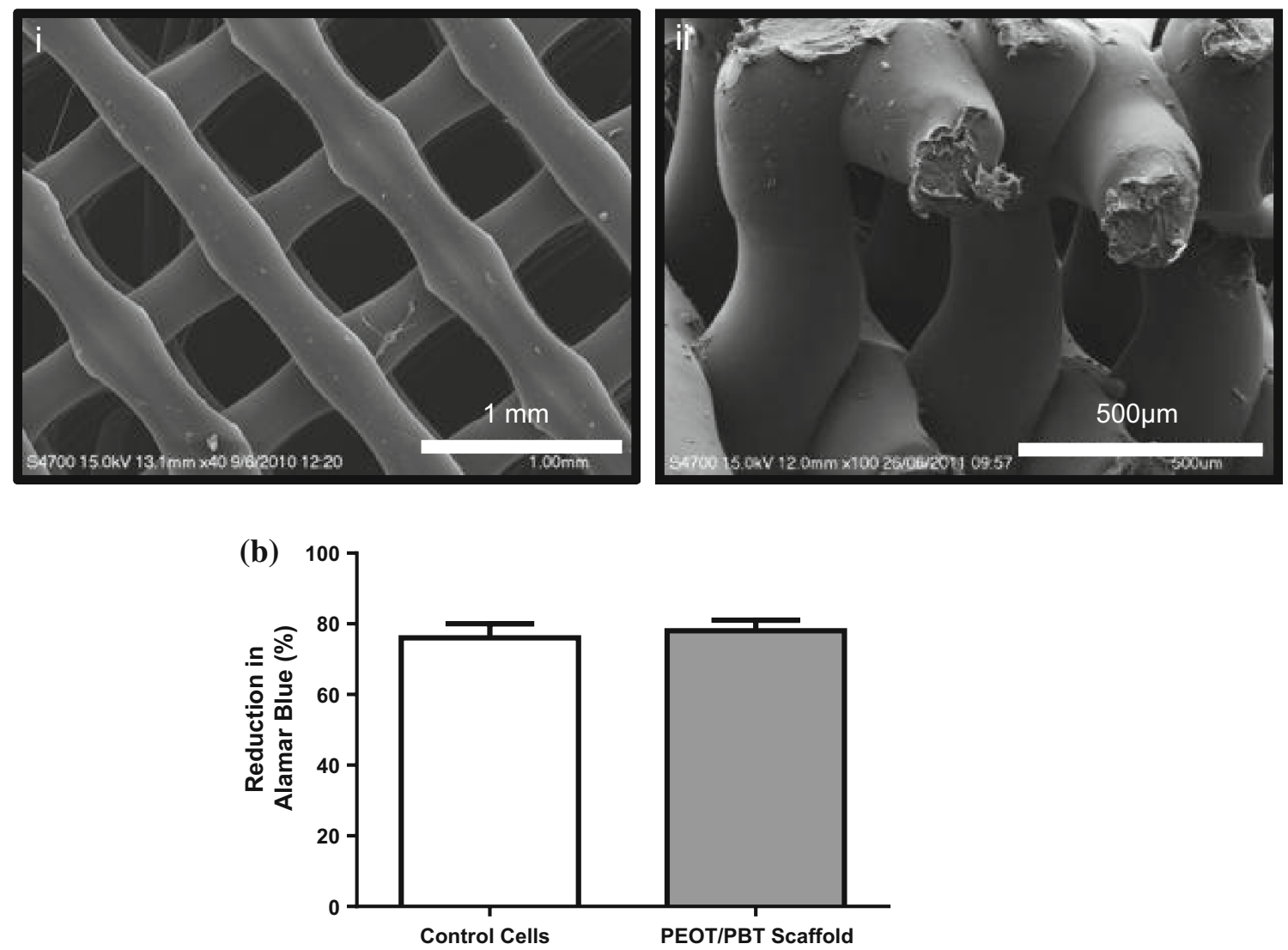

FIGURE 1. Materials characterisation with (a) SEM images showing the 3D scaffold architecture from i top view and ii crosssection; (b) viability of rabbit MSCs grown in the presence of the fabricated PEOT/PBT scaffold compared to controls on tissue culture plastic (TCP) with no statistical difference observed between groups.

\section{RESULTS}

\section{In Vitro Optimisation of the Scaffold}

As shown in Fig. 1a, SEM analysis demonstrated that the 3D PEOT/PBT scaffolds had a strut diameter of $296 \pm 52 \mu \mathrm{m}$ and a pore size of $512 \pm 22 \mu \mathrm{m} \times 476 \pm$ $25 \mu \mathrm{m} \times 180 \pm 30 \mu \mathrm{m}$. Cell survival in the presence of the 3D PEOT/PBT scaffold was assessed with an AlamarBlue $^{\mathrm{TM}}$ assay and indicated that there was no statistical difference detected in the cell metabolic activity of rabbit MSCs grown on tissue culture plastic (TCP) or MSCs grown in the presence of the PEOT/PBT scaffolds (Fig. 1b) The optimal cell attachment and distribution of rabbit MSCs on the PEOT/PBT scaffolds was determined using a cell seeding density of $25 \times 10^{6}$ cells $/ \mathrm{ml}$ and is shown in Fig. 2a, b. A statistically greater number of cells were retained on scaffolds pre-treated with $50 \mu \mathrm{g} / \mathrm{ml}$ fibronectin, with over a sevenfold increase in cell retention over no coating, 3 times greater loading compared to the use of $25 \mu \mathrm{g} / \mathrm{ml}$ and almost twice that of $100 \mu \mathrm{g} / \mathrm{ml}$ fibronectin (Fig. 2a) with average values of 50,000 , $210,000,580,000$, and 320,000 for $0,25,50$, and $100 \mu \mathrm{g} / \mathrm{ml}$ of fibronectin, respectively. This is further evidenced in the
SEM images, where a greater number of cells were seen to attach to the scaffold with the $50 \mu \mathrm{g} / \mathrm{ml}$ coating of fibronectin (Fig. 2b).

With respect to the differentiation behavior of the rabbit MSC-seeded scaffolds in vitro, the provision of biological signals for chondrogenesis was confirmed as evidenced by the GAG accumulation observed in both hypoxic and normoxic environments (Fig. 2c). After 21 days culture in the presence of TGF $\beta_{3}, 18 \pm 12 \mu \mathrm{g} /$ $\mu \mathrm{g}$ of GAG/DNA was measured for hypoxia cultured samples compared to $10 \pm 4 \mu \mathrm{g} / \mu \mathrm{g}$ of $\mathrm{GAG} / \mathrm{DNA}$ recorded for cell-seeded scaffolds cultured in normoxia. In the absence of $\operatorname{TGF} \beta 3,6.5 \pm 4.5 \mu \mathrm{g} / \mu \mathrm{g}$ GAG/DNA was recorded for samples cultured in hypoxia compared to $4.5 \pm 4 \mu \mathrm{g} / \mu \mathrm{g}$ of $\mathrm{GAG} / \mathrm{DNA}$ recorded in normoxia, with statistical significance observed between samples cultured in hypoxia with TGF $\beta 3$ and in normoxia without TGF $\beta 3$.

\section{Histological Evaluation of Repair}

Figure 3 shows representative images of toluidine blue stained sections of the complete rabbit condyle 


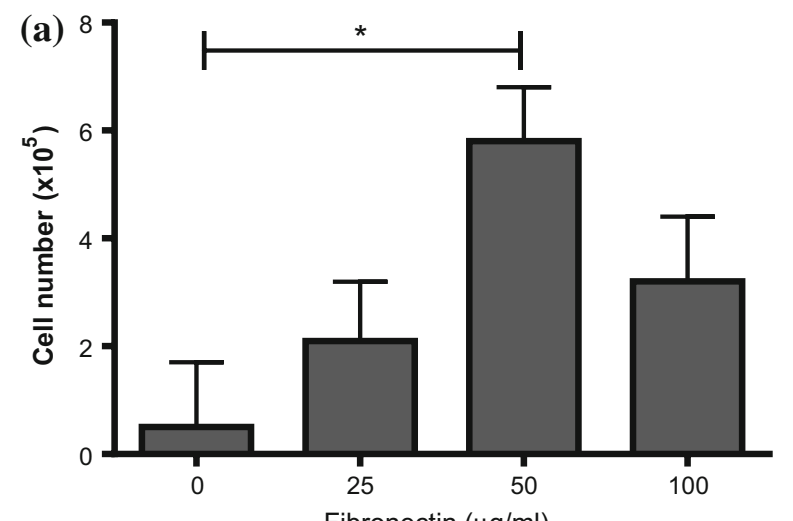

(b)
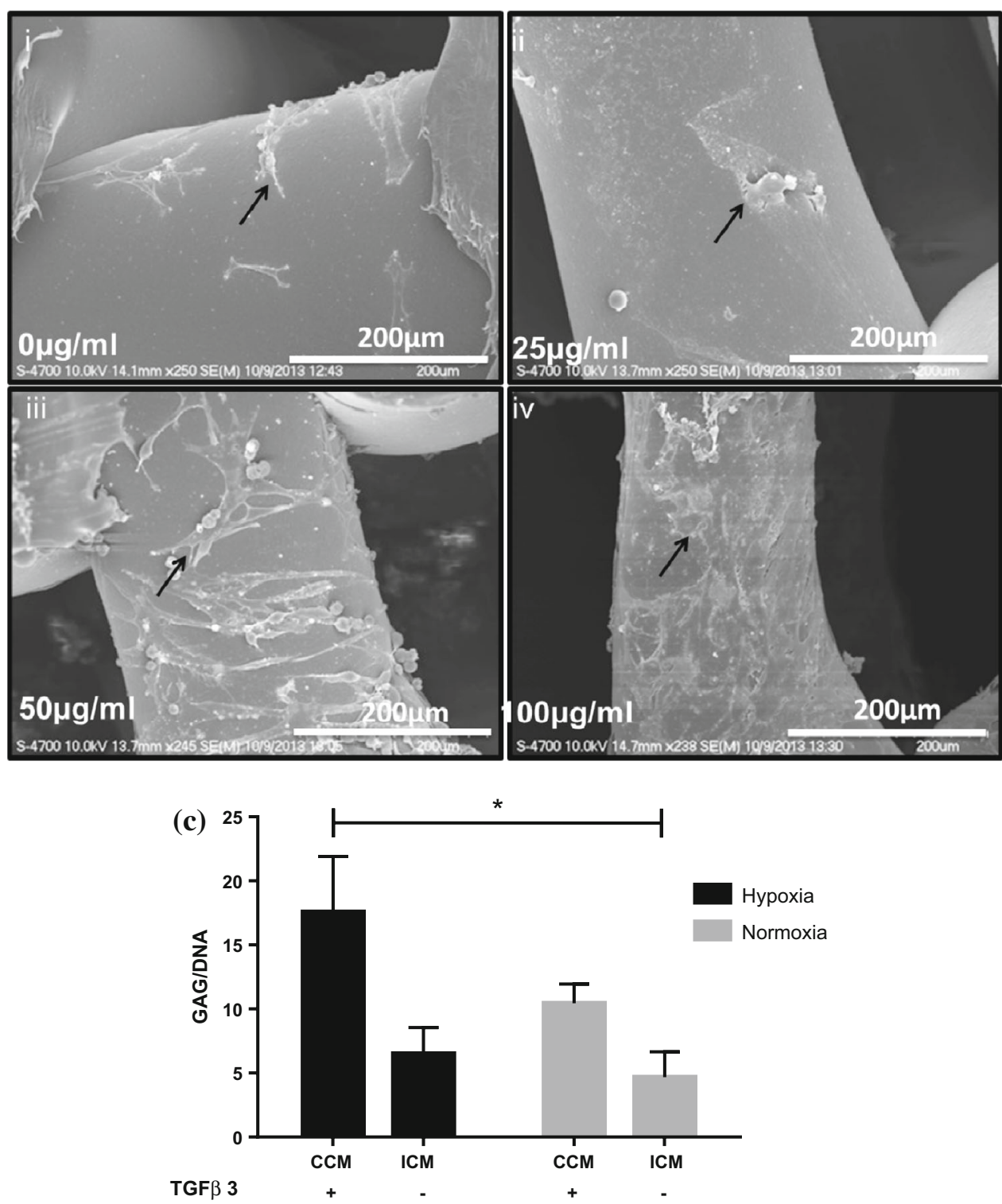

FIGURE 2. (a) Cell seeding optimisation showing the greatest number of cells remaining on the scaffolds at $24 \mathrm{~h}$. using $50 \mu \mathrm{g} / \mathrm{ml}$ fibronectin $(n=3)$, with *indicating $p \leq 0.05$; (b) representative SEM images showing cell attachment on scaffolds coated with $i$ $0 \mu \mathrm{g} / \mathrm{ml}$ fibronectin; ii $25 \mu \mathrm{g} / \mathrm{ml}$ fibronectin; iii $50 \mu \mathrm{g} / \mathrm{ml}$ fibronectin, and iv $100 \mu \mathrm{g} / \mathrm{ml}$ fibronectin. Black arrows show cells on scaffold struts; (c) in vitro chondrogenesis of rabbit MSCs loaded on PEOT/PBT scaffolds represented by GAG/DNA accumulation in hypoxic and normoxic cell culture environments \pm TGF $\beta 3$ with *indicating $p \leq 0.05$. 


\section{Empty Defect}

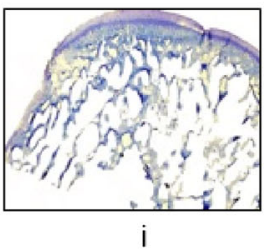

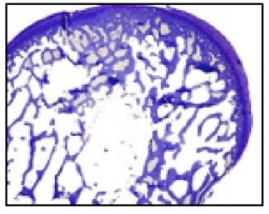

ii

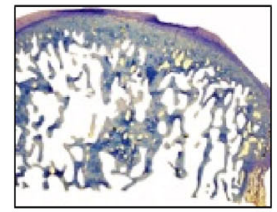

iii

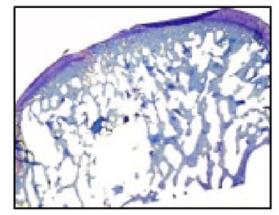

iv

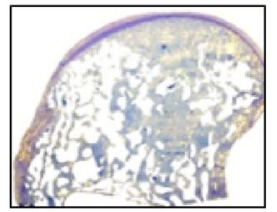

v

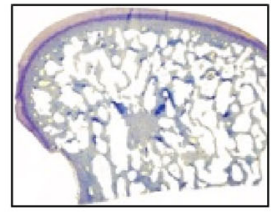

vi

Cell-free PEOT/PBT Scaffold

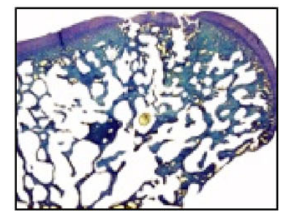

vii

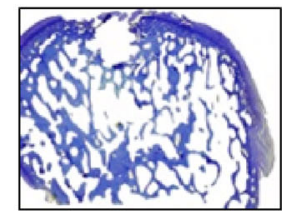

viii

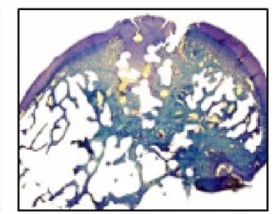

ix

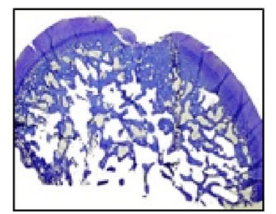

$x$

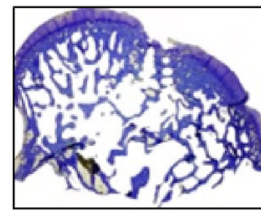

xi

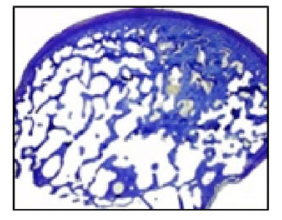

xvii

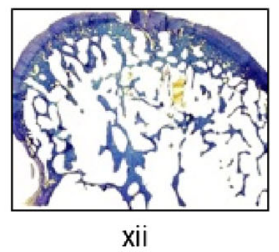

xii

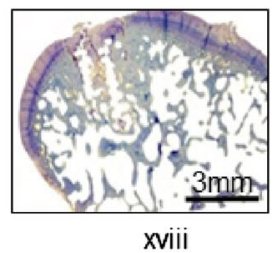

FIGURE 3. a Light microscopy images showing toluidine blue staining of cartilage repair i-vi in the empty defects, vii-xii the cellfree PEOT/PBT scaffolds, and xiii-xvii the rabbit MSC-seeded scaffolds after 12 weeks implantation, magnification $\times 1.25$.

12 weeks after implantation. Cartilage repair was observed in empty defects, as well as in defects containing cell-free and cell-seeded scaffolds. It can also be seen that the PEOT/PBT scaffold has not completely degraded suggesting that mechanical support was provided throughout the 12 -week period. Moreover, it appears that the presence of the cells provided a better environment for repair with fewer large defects observed in comparison to the cell-free scaffold group. However, on closer examination, the quality of repair was not the same. As seen previously with rabbit models, cartilage repair in empty defects was observed after 12 weeks, with 2 of the 6 replicates (Fig. 3Av and 3Avi) showing a thin line of organized cartilage repair and surface continuity, and 3 of the 6 showing a tidemark (Fig. 3Ai, $3 \mathrm{Av}$, and 3Avi). Moreover, 3 replicates (Fig. 3Aii, 3Aiii, and 3 Aiv) also showed evidence of degenerative changes (moderate hypo or hypercellularity) in the adjacent tissue, chondrocyte clustering and degenerative changes in the repair tissue.

With respect to the cell-free PEOT/PBT scaffolds, hyaline cartilage morphology was not observed in any of the defects; there was no evidence of a smooth articular surface and there was no tidemark present in the six replicates. The thickness of the repair tissue approached that of native tissue in 1 of 6 replicates and this was accompanied by partial integration with the native cartilage (Fig. 3Aix). There was also some evidence of integration at one side of $2 / 6$ replicates (Fig. 3Avii and 3Axii). There were no degenerative changes (slight to moderate hypo or hypercellularity) observed in the newly formed cartilage tissue, however, there were degenerative changes observed in the adjacent host cartilage in $50 \%$ of replicates (Fig. 3Aviii, $3 \mathrm{Ax}$, and $3 \mathrm{Axi})$. Regarding the cell-seeded scaffolds, a thin layer of cartilage was observed in $50 \%$ of the samples (Fig. 3xiii, 3Axiv, and 3Axvii). The thickness of the cartilage repair tissue and integration with native tissue was also improved, with half of the samples (Fig. 3Axiii, 3Axiv, and 3Axvii) approaching thickness of native cartilage tissue and $50 \%$ of showing integration with native tissue (Fig. 3Axiii, 3Axiv, and 3Axvii).

In relation to chondrogenesis, there was evidence of GAG accumulation in the empty defect and in and around the scaffolds struts of the cell-free scaffold (Fig. 4). Chondrocyte cells were observed in their lacunae above the tidemark in the cell-seeded scaffolds (Fig. 4Cii-iii). There was evidence of hypocellularity in the cell-free scaffolds (Fig. 4Biii-iv). In addition, chondrocyte clusters were observed in the cell-seeded constructs (Fig. 4Civ) and the adjacent cartilage at the margin of the defect in the empty defects (Fig. 4Aiii-iv). 
(a)
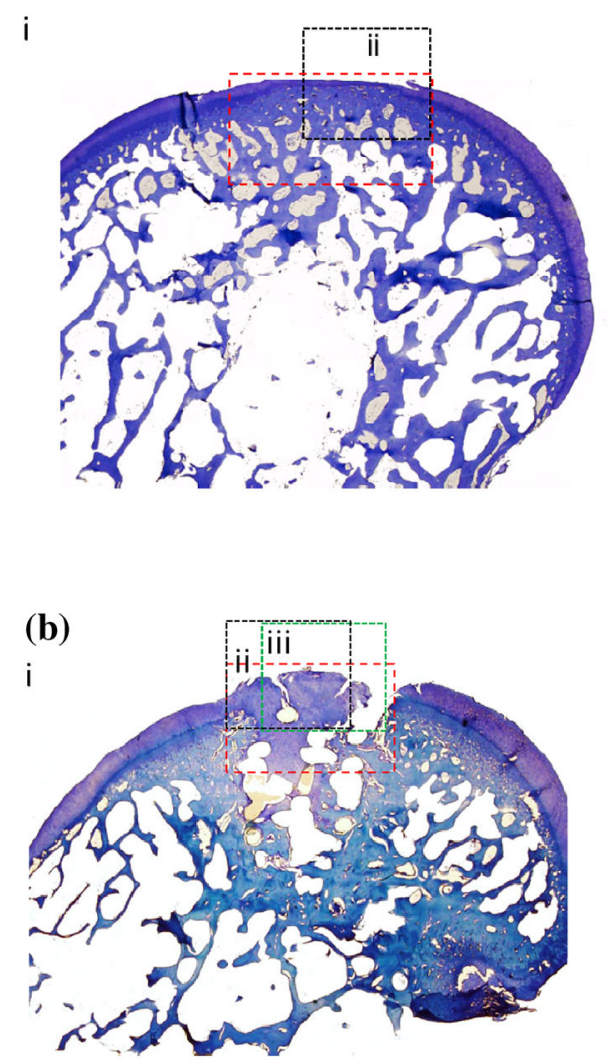

(c)

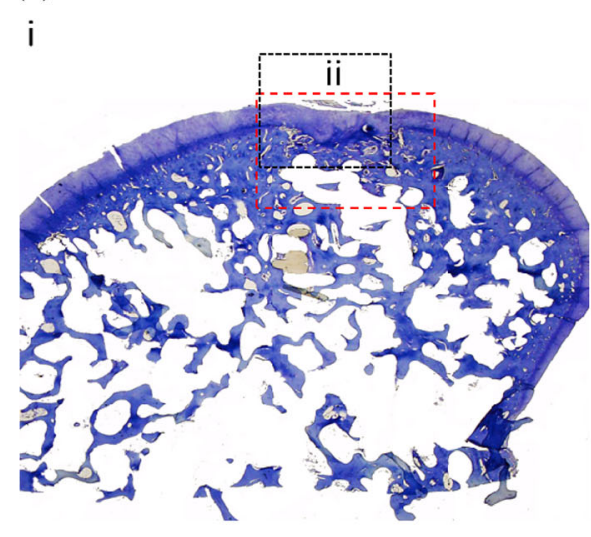

ii

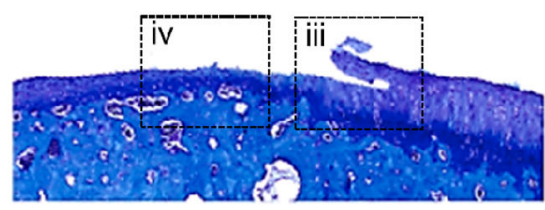

iii

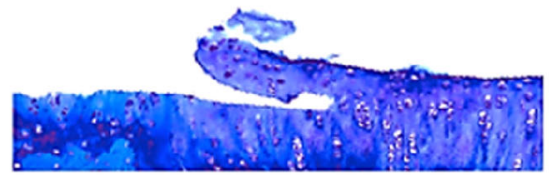

iv

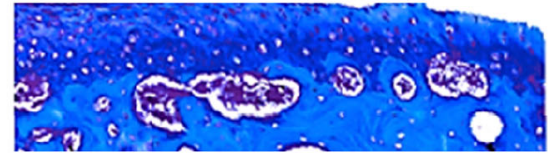

ii

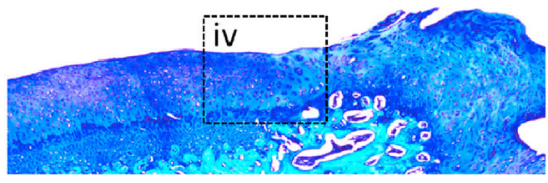

iii

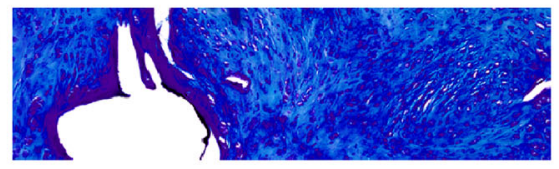

iv

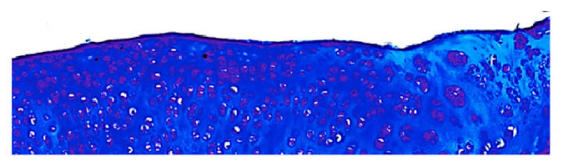

ii

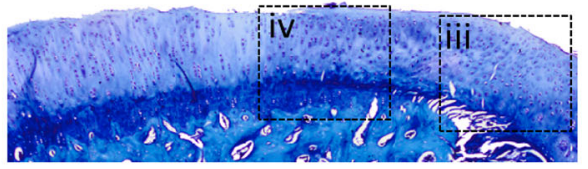

iii

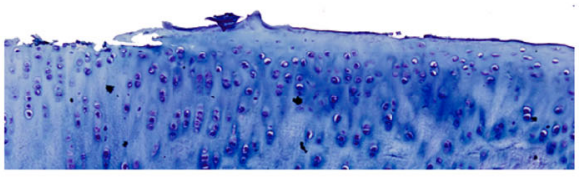

iv

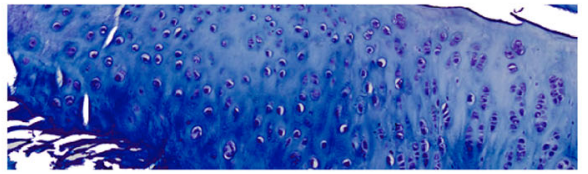

FIGURE 4. Representative images showing toluidine blue staining for chondrogenesis and GAG accumulation in (a) an empty defect; (b) a cell-free PEOT/PBT scaffold, and (c) a rabbit MSC-seeded scaffold, with insets taken at higher magnifications of $\times 4$ and $10 \times$ to show tissue repair at the edge and the center of the defects as highlighted by dotted black boxes. Dotted red box shows original defect site areas.

\section{Histological Scoring of Repair Tissue}

Histological scoring was conducted by four blinded evaluators using a modified O'Driscoll scoring system (Table 1). As shown in Fig. 5a, the data generated for repair appeared to be consistent with the observations for toluidine blue staining for chondrogenesis and GAG formation (Fig. 3). The empty defect appeared to promote the best repair, while the cell- 
TABLE 1. Modified O'Driscoll histological scoring system used to grade 12-week cartilage repair specimens.

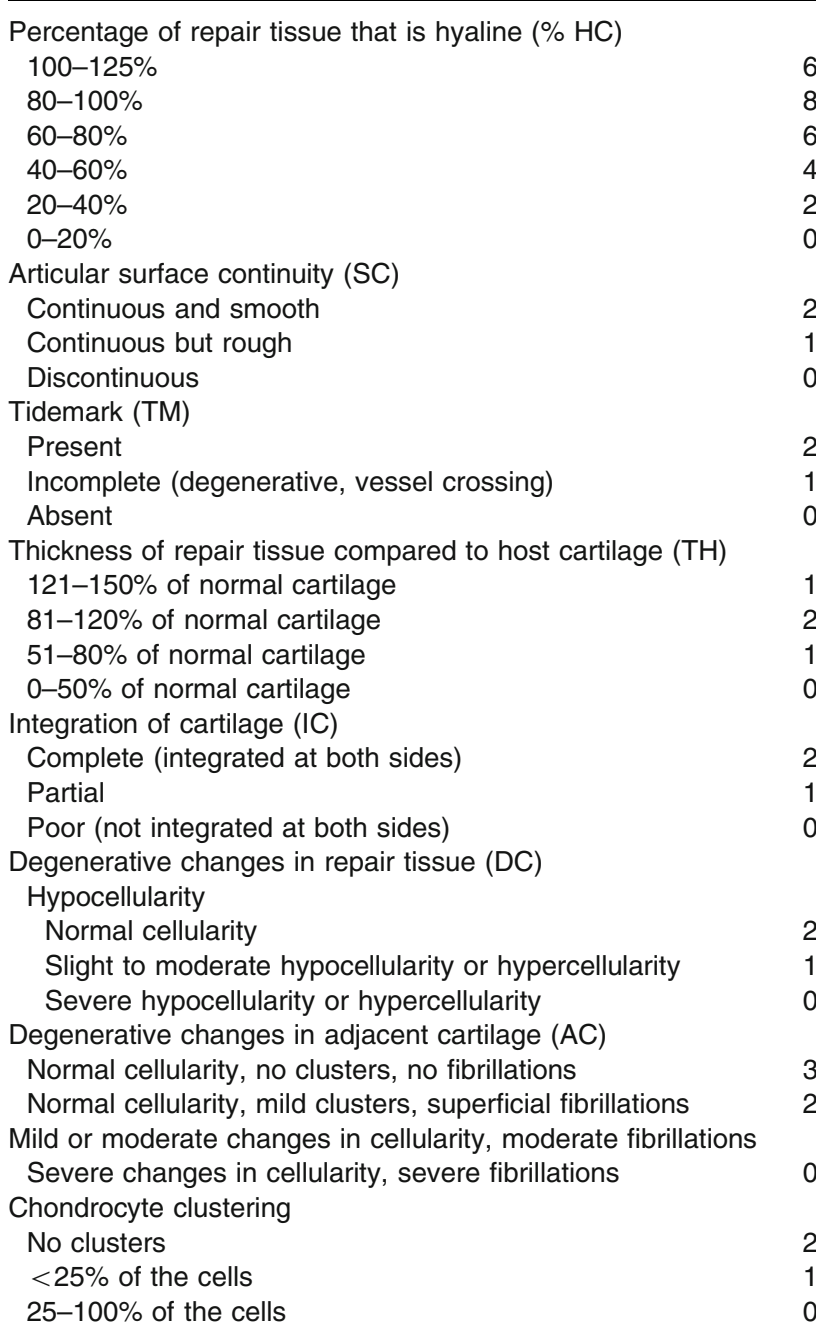

seeded scaffold promoted statistically significant better repair compared to the cell-free scaffold. In particular, the poorest percentage hyaline cartilage formation was observed for the cell-free scaffold, with statistically significant differences recorded between the empty defect and the cell-seeded scaffold for percentage hyaline cartilage, surface continuity and thickness of repair. The scoring also reflected the poor tidemark observed in both the cell-free and cell-seeded scaffolds, where significant differences were observed between both scaffolds and the empty defect, which may be due to the presence of the scaffold itself. With respect to integration and degeneration, the cell-free scaffold scored lowest with respect to integration, degenerative changes and chondrocyte clustering with statistically significant differences observed between the cell-seeded scaffold and empty defect. Despite the fact that the empty defect appeared to have statistically better repair than the scaffold groups, it also had the largest variations within its group as shown with the confidence of intervals at $95 \%$ (Table 2).

\section{Collagen Formation}

With respect to fibrocartilage formation, evidence of collagen I was observed throughout the tissue fill in the empty defect (Fig. 6Ai-ii), while was absent in the adjacent native tissue (Fig. 6Aiii-iv). Repair tissue in the cell-free scaffolds also stained positive for type I collagen with intense staining throughout equivalent to that of adjacent normal bone indicating fibrous cartilage repair (Fig. 6Av-vi). On the other hand staining in cell-loaded scaffolds was detected to a much lesser extent with intensity almost equivalent to background in some areas (Fig. 6Aix-x). Nonetheless, collagen type I was detected in the border zone and at the surface of the repair tissue in the cell-seeded scaffolds (Fig. 6Aix).With respect to collagen type II (Fig. 6b), there was evidence of staining in the empty defect (Fig. 6Bi-iv) and in both the cell-free (Fig. 6Bv-viii) and MSC-seeded scaffolds (Fig. 6Bix-xii). As in the case of the collagen type I staining, the tideline was expanded in the cell-free (Fig. 6Bv) and cell-seeded scaffolds (Fig. 6Bix), with collagen type II staining observed above the tideline in the cartilage zone. Visually, the cell-seeded scaffold appeared to have more hyaline cartilage as evidenced by collagen type II and less fibrocartilage as evidenced by collagen type I staining when compared to the cell-free scaffold and the empty defect.

With respect to bone repair, bone cysts were observed in $50 \%$ of the empty defects. There was no difference observed between the structural integrity of the bone in the defects containing cell-free scaffolds when compared to cell-seeded scaffolds (Fig. 3). However, in terms of bone structure, the cell-seeded scaffold promoted better repair. Additionally, no bone cysts were observed for either the cell-free or cell-seeded scaffolds, as compared to the empty defect.

\section{DISCUSSION}

Hyaline cartilage repair is the ultimate clinical goal for damaged or osteoarthritic cartilage. Although previous research has shown that open-pore scaffolds allow cell migration through the scaffold in vivo, architecture alone is not the only requirement for optimal hyaline cartilage repair. Recent studies have suggested that the material property requirements of a scaffold for cartilage repair are a multifactorial problem that delicately balances scaffold architecture and mechanical properties together with biological cues. In the current study, we tested the hypothesis that in 
(a) Percentage Hyaline Cartilage
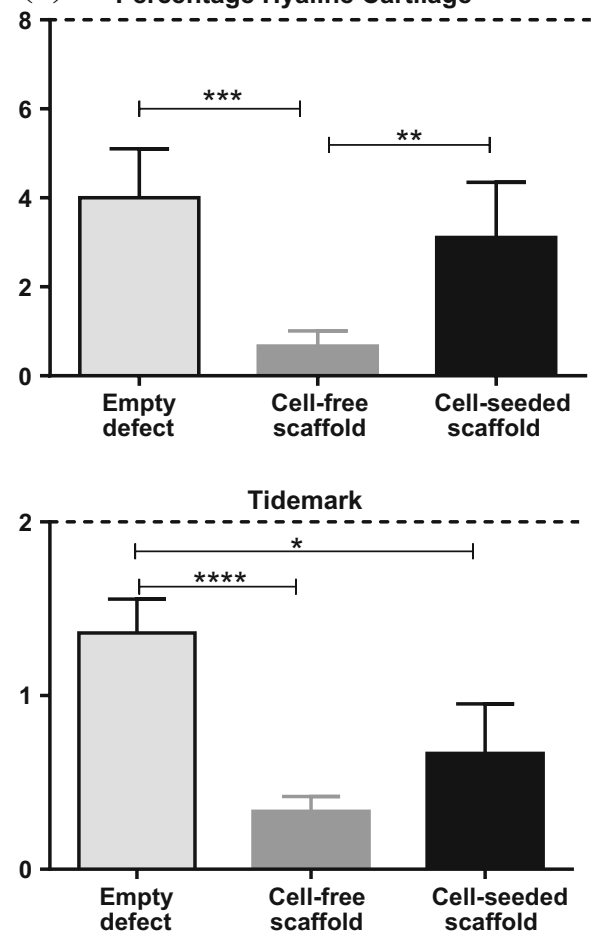

(b)

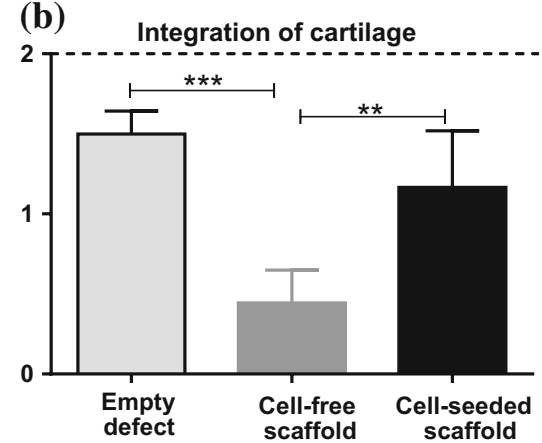

Degenerative changes in adjacent cartilage

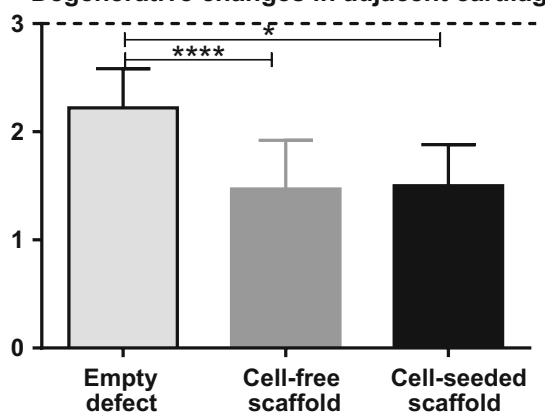

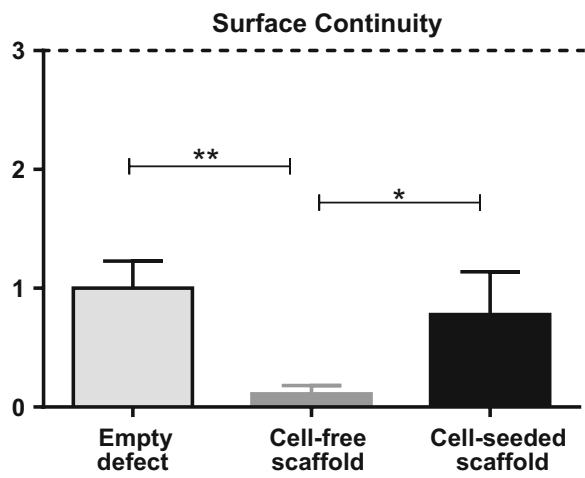

Thickness of repair tissue

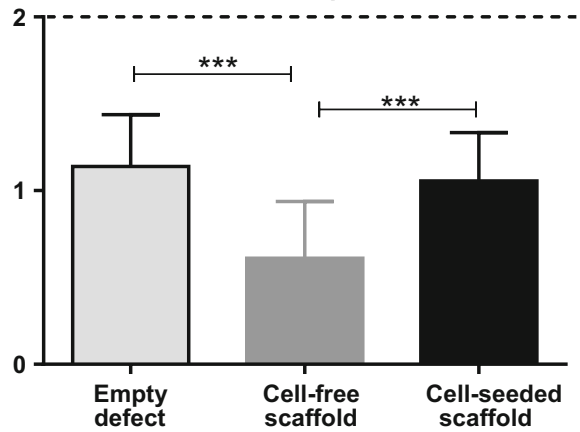

Degenerative changes in repair tissue
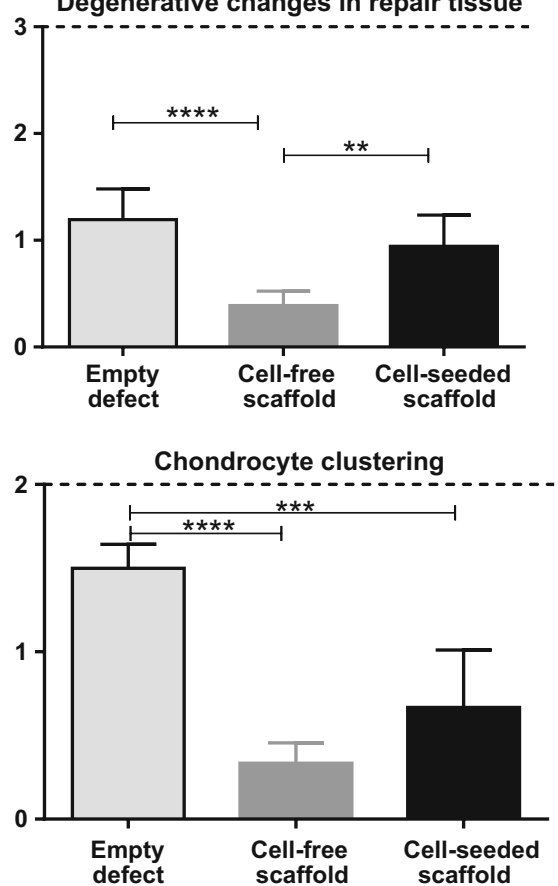

FIGURE 5. Scores generated using a modified O'Driscoll scoring system for histological evaluation of (a) Tissue repair (b) Integration and degeneration of repair tissue and adjacent tissue for empty defects, cell-free scaffolds and cell-seeded scaffolds. Dotted lines indicate the highest possible score and $p \geq 0.05$ considered not significant $(\mathrm{ns}),\left({ }^{*}\right), p \leq 0.01$ very significant $(* *)$, with $\left.p \leq 0.001{ }^{(\star \star}\right)$, and $\left.p \leq 0.00001{ }^{(* \star *}\right)$ considered extremely significant. (Results are representative of blinded evaluations performed by 4 evaluators. Values plotted are mean \pm SEM). 
BARRON et al.

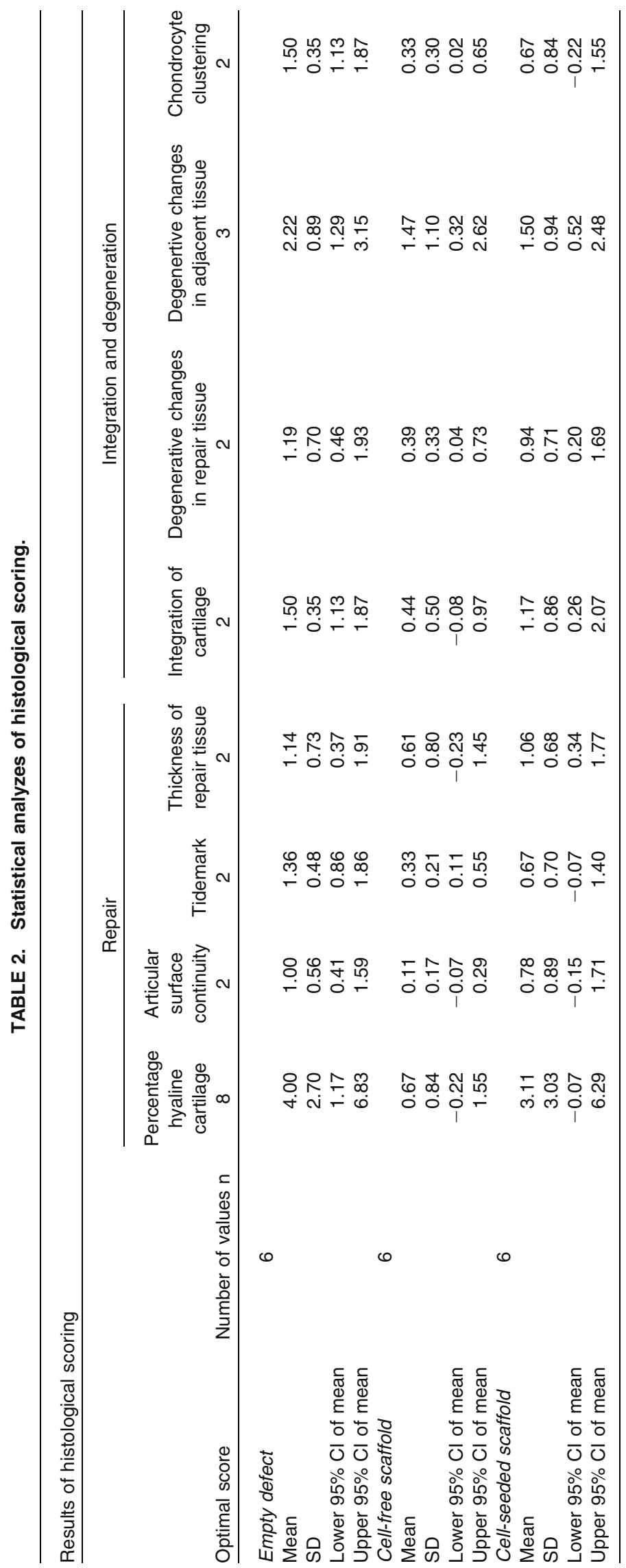


(a)

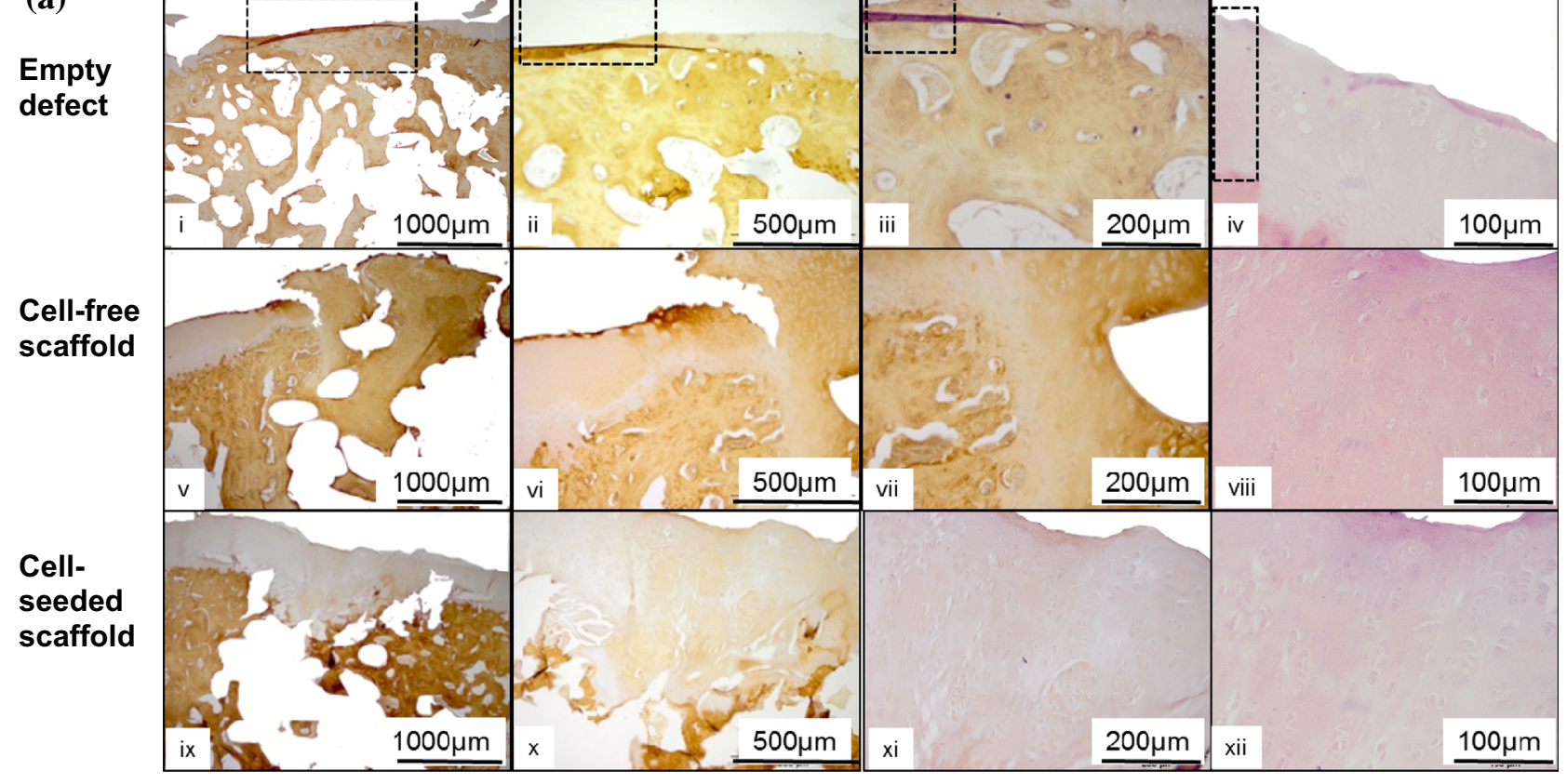

(b)

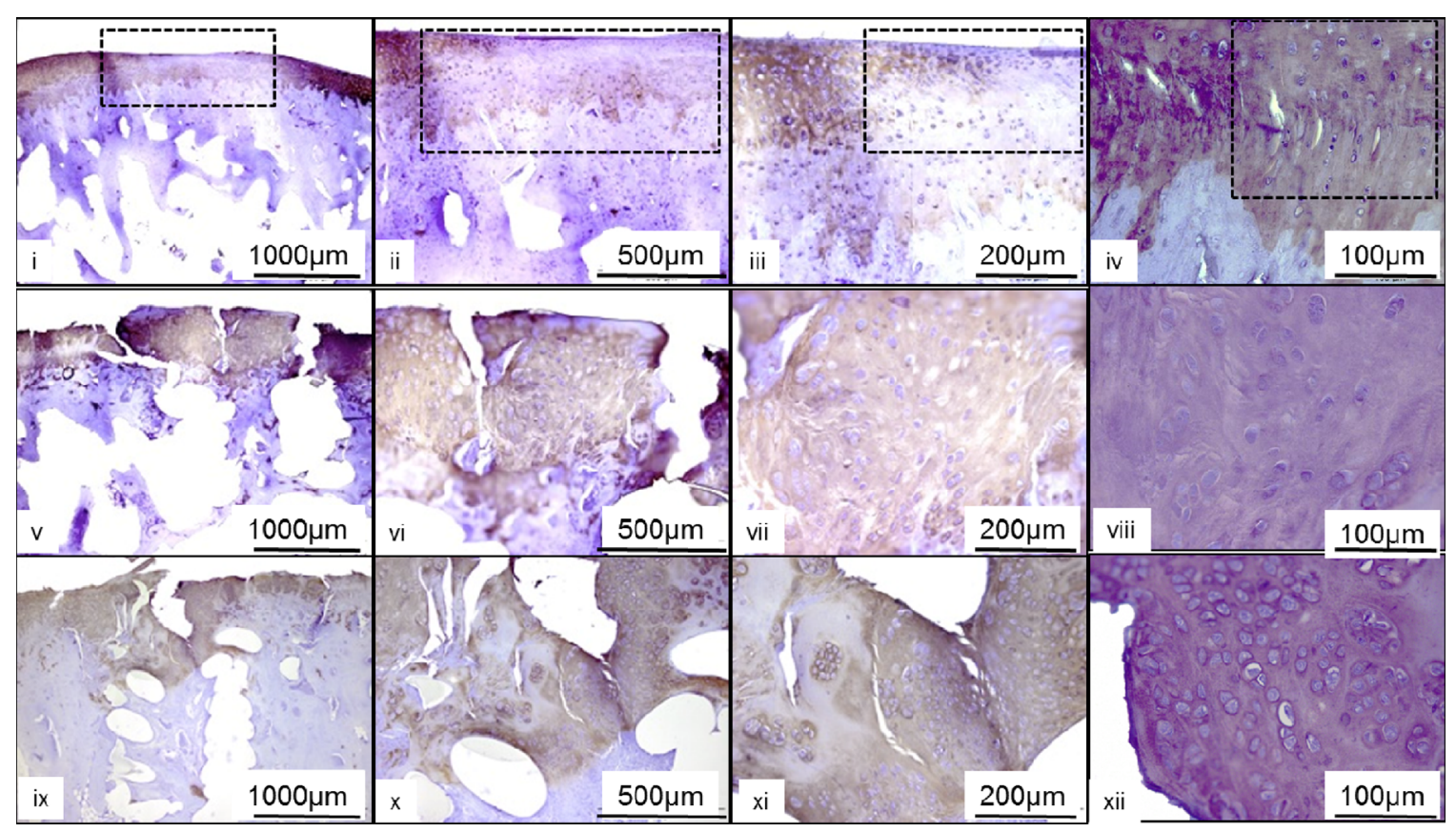

FIGURE 6. (a) Immunohistological staining for collagen type I for i-iv a representative empty defect; v-viii a cell-free PEOT/PBT scaffold, and ix-xii a rabbit MSC-seeded scaffold; (b) Immunohistological staining for collagen type II counterstained with Harris haematoxylin for i-iv a representative empty defect; $v$-viii a cell-free PEOT/PBT scaffold, and ix-xii a rabbit MSC-seeded scaffold. Images show increasing magnification from left to right: $\times 2, \times 4, \times 10$, and $\times 20$, respectively. Dotted lines demarcate the repair tissue in the empty defects and the adjacent native tissue.

combination with fine-tuned mechanical properties, the addition of MSCs would provide biological cues for better repair. Hyaline cartilage repair was assessed in terms of toluidine blue staining for chondrogenesis and GAG formation together with collagen type II staining. Evidence of fibrocartilage formation was examined using collagen type I staining.

In an effort to create an open-pore scaffold with finely tuned chemical and mechanical properties, PEOT/PBT scaffolds were fabricated using the clini- 
cally scalable and reproducible rapid prototyping method of 3D fiber deposition. Prior to implantation these scaffolds were evaluated in terms of architecture, cell survival, optimal loading conditions and in vitro chondrogenesis. The 3D architecture of the scaffold and values measured for the strut diameter $(296 \pm 52 \mu \mathrm{m})$ and pore size $(512 \pm 22 \mu \mathrm{m} \times 476 \pm$ $25 \mu \mathrm{m} \times 180 \pm 30 \mu \mathrm{m})$ were in accordance with design parameters and are comparable with structures previously used for cartilage repair. ${ }^{5,21,32} \mathrm{In}$ an attempt to optimize cell loading, the optimal concentration of fibronectin coating was evaluated. Cell attachment on biomaterials coated with the extracellular matrix protein fibronectin has been shown to interact through the RGD (arg-gly-asp) ligand within fibronectin and integrins such as $\alpha_{5} \beta_{1}$ and $\alpha_{5} \beta_{3}{ }^{19,27}$ It has also been shown that cell adhesion is mediated by the confirmation and spatial distribution of RGD ligands. ${ }^{17}$ Moreover, it has been shown that there is an optimal RGD density for cell attachment. ${ }^{11,19}$ In this study, fibronectin coating of the scaffold at $50 \mu \mathrm{g} / \mathrm{ml}$ in combination with a cell seeding density of $25 \times 10^{6}$ cells $/ \mathrm{ml}$ or $1.2 \times 10^{6}$ cells/scaffold, as used previously, ${ }^{10}$ resulted in optimal cell loading. Above $50 \mu \mathrm{g} / \mathrm{ml}$ fibronectin, a decrease in cell attachment and a change in cell morphology was observed. This correlates with the findings of Massia and Hubbell, ${ }^{19}$ where a decrease in cell attachment and a change in morphology was shown above a threshold value in RDG ligand density and associated fibronectin concentration. Furthermore, the MSCs were seen to be attached to the scaffold struts and distributed throughout the 3D construct as proposed by Jansen for optimal cartilage repair. ${ }^{8}$ With respect to the MSC differentiation behavior in vitro, GAG accumuluation after 21 days culture in the presence of $\mathrm{TGF} \beta_{3}$ in both normoxic and hypoxic conditions compared well to other studies, ${ }^{3,20}$ with GAG/DNA values in hypoxia almost twice that observed in normoxia when cultured in the presence of TGF $\beta 3$.

Rabbit models are known to have limitations, ${ }^{4,6,7,26}$ but are recognized by the International Cartilage Repair Society (ICRS) as a suitable animal model for proof of principle studies. ${ }^{6,7}$ Rabbits are less expensive than large animal models and provide useful information for screening formulations and developmental studies. ${ }^{4}$ Nonetheless, one of the disadvantages of using a rabbit model is that rabbits exhibit spontaneous repair, albeit with degenerative changes and evidence of arthritis. ${ }^{1,4,29}$ In this study, an osteochondral defect was created in a rabbit model. After 12-weeks, the empty defect showed evidence of cartilage repair. On closer examination, there was evidence of chondrocyte clustering and hypo- and hyper-cellularity in the repair and native tissues, which compares well with previous findings and is perhaps why empty defects are accepted as a negative control. ${ }^{7}$ To determine whether the addition of MSCs to the scaffold would enhance repair, rabbit MSCs were seeded in the scaffold and implanted in a rabbit osteochondral defect. On initial examination of toluidine blue staining for chondrogenesis and GAG, it appeared that tissue repair was successful in the empty defect, but when collagen staining was taken into account the repair tissue was seen to be fibrocartilage as evidenced by the presence of collagen type I and the absence of collagen type II. The tissue repair in the cell-free scaffold appeared to have reduced chondrogenesis and GAG formation, and stained positive for both collagen type I and collagen type II. In contrast, chondrogenesis, GAG formation and staining for collagen type II were observed in the cell-seeded scaffold, echoing the observations of Maehara when cells were present. ${ }^{16}$

When comparing the histological scoring between the groups, the cell-free scaffold had statistically poorer repair when compared to the cell-seeded scaffold and the empty defect. These results suggest that the scaffold alone may impede cell migration and repair. However, in the presence of MSCs hyaline cartilage repair was observed, suggesting the cells provide biological signals, despite the fact that the scaffold has not fully degraded. Balancing mechanical properties, degradation rate and inflammation is a delicate process, which may be achieved by altering the chemical nature of the scaffold. By altering the degradation rate, the mechanical properties and surface chemistry will also change, which may introduce inadequate support or an inflammatory response. Nonetheless, the PEOT/ PBT scaffold did not produce an inflammatory response or cyst formation in agreement with previous studies. ${ }^{12,28}$ Taken together, these results suggest that longer time points to evaluate tissue repair are required rather than changing the chemical structure and degradation rate.

With respect to limitations of the study, the number of specimens and the number of time points examined are noted. Regarding, statistical analysis, the number of specimens examined $(n=6)$ for each group was sufficient to compare the scores between groups. However, for comparison within the groups, the numbers were too low for a Kruskal-Wallis nonparametric analysis. Although, the confidence of interval values at $95 \%$ revealed that the greatest variations were observed for the empty defect group, a powered study with larger $n$ numbers would provide more statistically relevant data. Regarding time points, a range of different time points have been examined for cartilage repair, with 12 -week studies recommended by the ICRS for proof of principle studies involving cellladen scaffolds and longer time points of 6 and 12 months recommended once proof of principle has 
been established. ${ }^{7}$ Since the cell-seeded scaffold demonstrated more evidence of hyaline cartilage compared to the cell-free scaffold and the empty defect, a powered study, in large animals with larger $n$ numbers and longer time points could be considered for examination of hyaline cartilage repair, scaffold degradation, mechanical properties and biochemical matrix evaluation.

In summary, these results suggest that the cell-seeded PEOT/PBT scaffold provides both biological cues and mechanical support with more hyaline-like tissue repair. Nonetheless, further studies are required to assess the potential of the MSC-seeded scaffold structure to support long term remodeling of the hyaline cartilage and underlying bone.

\section{ACKNOWLEDGMENTS}

This work was supported by Science Foundation Ireland (SFI) Strategic Research Cluster (SRC), Grant No. SFI: 09/SRC B1794, Wellcome Trust Biomedical Vacation Scholarships Grant Number WTD004448, the European Union's 7th Framework Programme under Grant Agreement No. HEALTH-2007-B223298 (PurStem).

\section{REFERENCES}

${ }^{1}$ Anderson, J. A., D. Little, A. P. Toth, C. T. Moorman, B. S. Tucker, M. G. Ciccotti, and F. Guilak. Stem cell therapies for knee cartilage repair: the current status of preclinical and clinical studies. Am. J. Sports Med. 2013. doi: $10.1177 / 0363546513508744$.

${ }^{2}$ Bhosale, A. M., and J. B. Richardson. Articular cartilage: structure, injuries and review of management. Br. Med. Bull. 87:77-95, 2008.

${ }^{3}$ Christensen, B. B., C. B. Foldager, O. M. Hansen, A. A. Kristiansen, D. Q. S. Le, A. D. Nielsen, J. V. Nygaard, C. E. Bünger, and M. Lind. A novel nano-structured porous polycaprolactone scaffold improves hyaline cartilage repair in a rabbit model compared to a collagen type I/III scaffold: in vitro and in vivo studies. Knee Surg. Sports Traumatol. Arthrosc. Off. J. ESSKA 20:1192-1204, 2012.

${ }^{4}$ Chu, C. R., M. Szczodry, and S. Bruno. Animal models for cartilage regeneration and repair. Tissue Eng. Part B Rev. 16:105-115, 2010.

${ }^{5}$ Emans, P. J., E. J. P. Jansen, D. van Iersel, T. J. M. Welting, T. B. F. Woodfield, S. K. Bulstra, J. Riesle, L. W. van Rhijn, and R. Kuijer. Tissue-engineered constructs: the effect of scaffold architecture in osteochondral repair. $J$. Tissue Eng. Regen. Med., 2012. doi:10.1002/term.1477.

${ }^{6}$ Hoemann, C., R. Kandel, S. Roberts, D. B. F. Saris, L. Creemers, P. Mainil-Varlet, S. Méthot, A. P. Hollander, and M. D. Buschmann. International cartilage repair society (ICRS) recommended guidelines for histological endpoints for cartilage repair studies in animal models and clinical trials. Cartilage 2:153-172, 2011.

${ }^{7}$ Hurtig, M. B., M. D. Buschmann, L. A. Fortier, C. D. Hoemann, E. B. Hunziker, J. S. Jurvelin, P. Mainil-Varlet, C. W. McIlwraith, R. L. Sah, and R. A. Whiteside. Preclinical studies for cartilage repair recommendations from the international cartilage repair society. Cartilage 2:137152, 2011.

${ }^{8}$ Jansen, E. J. P., J. Pieper, M. J. J. Gijbels, N. A. Guldemond, J. Riesle, L. W. Van Rhijn, S. K. Bulstra, and R. Kuijer. PEOT/PBT based scaffolds with low mechanical properties improve cartilage repair tissue formation in osteochondral defects. J. Biomed. Mater. Res. A 89:444452, 2009.

${ }^{9}$ Johnson, K., S. Zhu, M. S. Tremblay, J. N. Payette, J. Wang, L. C. Bouchez, S. Meeusen, A. Althage, C. Y. Cho, $\mathrm{X}$. Wu, and P. G. Schultz. A stem cell-based approach to cartilage repair. Science 336:717-721, 2012.

${ }^{10}$ Kavalkovich, K. W., R. E. Boynton, J. M. Murphy, and F. Barry. Chondrogenic differentiation of human mesenchymal stem cells within an alginate layer culture system. Vitro Cell. Dev. Biol. Anim. 38:457-466, 2002.

${ }^{11}$ Le Saux, G., A. Magenau, T. Böcking, K. Gaus, and J. J. Gooding. The relative importance of topography and RGD ligand density for endothelial cell adhesion. PLOS ONE 6:e21869, 2011.

${ }^{12}$ Lee, C. H., J. L. Cook, A. Mendelson, E. K. Moioli, H. Yao, and J. J. Mao. Regeneration of the articular surface of the rabbit synovial joint by cell homing: a proof of concept study. Lancet 376:440-448, 2010.

${ }^{13}$ Liu, Y., X. Z. Shu, and G. D. Prestwich. Osteochondral defect repair with autologous bone marrow-derived mesenchymal stem cells in an injectable, in situ, cross-linked synthetic extracellular matrix. Tissue Eng. 12:3405-3416, 2006.

${ }^{14}$ Longo, U. G., S. Petrillo, E. Franceschetti, A. Berton, N. Maffulli, and V. Denaro. Stem cells and gene therapy for cartilage repair. Stem Cells Int. 2012:168385, 2012.

${ }^{15}$ Mackle, J. N., D. J.-P. Blond, E. Mooney, C. McDonnell, W. J. Blau, G. Shaw, F. P. Barry, J. M. Murphy, and V. Barron. In vitro characterization of an electroactive carbon-nanotube-based nanofiber scaffold for tissue engineering. Macromol. Biosci. 11:1272-1282, 2011.

${ }^{16}$ Maehara, H., S. Sotome, T. Yoshii, I. Torigoe, Y. Kawasaki, Y. Sugata, M. Yuasa, M. Hirano, N. Mochizuki, M. Kikuchi, K. Shinomiya, and A. Okawa. Repair of large osteochondral defects in rabbits using porous hydroxyapatite/collagen $(\mathrm{HAp} / \mathrm{Col})$ and fibroblast growth factor-2 (FGF-2). J. Orthop. Res. Off. Publ. Orthop. Res. Soc. 28:677-686, 2010.

${ }^{17}$ Maheshwari, G., G. Brown, D. A. Lauffenburger, A. Wells, and L. G. Griffith. Cell adhesion and motility depend on nanoscale RGD clustering. J. Cell Sci. 113:16771686, 2000.

${ }^{18}$ Malda, J., T. B. F. Woodfield, F. van der Vloodt, C. Wilson, D. E. Martens, J. Tramper, C. A. van Blitterswijk, and J. Riesle. The effect of PEGT/PBT scaffold architecture on the composition of tissue engineered cartilage. Biomaterials 26:63-72, 2005.

${ }^{19}$ Massia, S. P., and J. A. Hubbell. An RGD spacing of $440 \mathrm{~nm}$ is sufficient for integrin alpha $\mathrm{V}$ beta 3-mediated fibroblast spreading and $140 \mathrm{~nm}$ for focal contact and stress fiber formation. J. Cell Biol. 114:1089-1100, 1991.

${ }^{20}$ Matsiko, A., T. J. Levingstone, F. J. O’Brien, and J. P. Gleeson. Addition of hyaluronic acid improves cellular 
infiltration and promotes early-stage chondrogenesis in a collagen-based scaffold for cartilage tissue engineering. $J$. Mech. Behav. Biomed. Mater. 11:41-52, 2012.

${ }^{21}$ Moroni, L., J. R. de Wijn, and C. A. van Blitterswijk. Three-dimensional fiber-deposited PEOT/PBT copolymer scaffolds for tissue engineering: influence of porosity, molecular network mesh size, and swelling in aqueous media on dynamic mechanical properties. J. Biomed. Mater. Res. A 75:957-965, 2005.

${ }^{22}$ Moroni, L., G. Poort, F. Van Keulen, J. R. de Wijn, and C. A. van Blitterswijk. Dynamic mechanical properties of $3 \mathrm{D}$ fiber-deposited PEOT/PBT scaffolds: an experimental and numerical analysis. J. Biomed. Mater. Res. A 78:605-614, 2006.

${ }^{23}$ Moutos, F. T., B. T. Estes, and F. Guilak. Multifunctional hybrid three-dimensionally woven scaffolds for cartilage tissue engineering. Macromol. Biosci. 10:1355-1364, 2010.

${ }^{24}$ Moutos, F. T., L. E. Freed, and F. Guilak. A biomimetic three-dimensional woven composite scaffold for functional tissue engineering of cartilage. Nat. Mater. 6:162-167, 2007.

${ }^{25}$ Murphy, J. M., D. J. Fink, E. B. Hunziker, and F. P. Barry. Stem cell therapy in a caprine model of osteoarthritis. Arthritis Rheum. 48:3464-3474, 2003.

${ }^{26}$ Reinholz, G. G., L. Lu, D. B. F. Saris, M. J. Yaszemski, and S. W. O'Driscoll. Animal models for cartilage reconstruction. Biomaterials 25:1511-1521, 2004.
${ }^{27}$ Ruoslahti, E. RGD and other recognition sequences for integrins. Annu. Rev. Cell Dev. Biol. 12:697-715, 1996.

${ }^{28}$ Shao, X., J. C. H. Goh, D. W. Hutmacher, E. H. Lee, and G. Zigang. Repair of large articular osteochondral defects using hybrid scaffolds and bone marrow-derived mesenchymal stem cells in a rabbit model. Tissue Eng. 12:15391551, 2006.

${ }^{29}$ Shapiro, F., S. Koide, and M. J. Glimcher. Cell origin and differentiation in the repair of full-thickness defects of articular cartilage. J. Bone Joint Surg. Am. 75:532-553, 1993.

${ }^{30}$ Solchaga, L. A., J. U. Yoo, M. Lundberg, J. E. Dennis, B. A. Huibregtse, V. M. Goldberg, and A. I. Caplan. Hyaluronan-based polymers in the treatment of osteochondral defects. J. Orthop. Res. Off. Publ. Orthop. Res. Soc. 18:773780, 2000.

${ }^{31}$ Valonen, P. K., F. T. Moutos, A. Kusanagi, M. G. Moretti, B. O. Diekman, J. F. Welter, A. I. Caplan, F. Guilak, and L. E. Freed. In vitro generation of mechanically functional cartilage grafts based on adult human stem cells and 3D-woven poly(epsilon-caprolactone) scaffolds. Biomaterials 31:2193-2200, 2010.

${ }^{32}$ Woodfield, T. B. F., J. Malda, J. de Wijn, F. Péters, J. Riesle, and C. A. van Blitterswijk. Design of porous scaffolds for cartilage tissue engineering using a three-dimensional fiber-deposition technique. Biomaterials 25:41494161, 2004. 